\title{
Research on Existing Problems and Improvement Measures of Fabricated Composite Wallboard
}

\author{
Ziyang $\mathrm{Yu}^{1, *}$, Yuqing $\mathrm{Hu}^{1}$, and Changhao Qin ${ }^{1}$ \\ ${ }^{1}$ School of Architecture and Engineering, Nanjing Institute of Technology, Nanjing, Jiangsu, 211167, China
}

\begin{abstract}
In recent years, fabricated composite wall panels have been widely used in building materials markets at home and abroad, and their main advantages are convenient construction, low energy consumption, and heat and sound insulation. However, fabricated composite wall panels also have some common problems in practical applications, such as large dead weight, weak seismic performance, prone to cracks, and failing to meet the higher energy-saving requirements of thermal insulation external walls. This article analyzes the board material and overall structure of the fabricated composite wallboard, proposes corresponding solutions to make up for its weakness in some performance, and gives the specific construction process and accuracy requirements.
\end{abstract}

\section{Introduction}

The green construction industry with prefabricated buildings as the main development direction is developing rapidly, and traditional manual construction methods can no longer adapt to the national "low-carbon economy" and "green environmental protection" building development concepts.[1]As the main part of the prefabricated building, the fabricated composite wall panel is to sandwich some functional materials between two wall panels made of a variety of building materials. The structure mainly includes the core insulation layer, internal partitions and these three parts of the outer partition.[2]At present, the fabricated composite wall panels on the market are generally reinforced concrete sandwich insulation panels, the inner and outer partitions are made of concrete, and the insulation layer is insulation boards such as rigid foam plastics, which are convenient for construction and consume more energy. The advantages of low heat insulation and sound insulation are ideal energy-saving walls for modern buildings, and there is a broad space for development in the field of prefabricated energy-saving buildings.[3]

\section{Problem statement of fabricated composite wallboard}

The prefabricated concrete composite wall panel, PC wall panel, is a wall panel mold made in advance. After the components are prefabricated in the factory through professional equipment, they are directly transported to the site for assembly. Its advantage is the close relationship between production and the cast-in-place structure process, the production experience of the castin-place structure can be transplanted well, the quality is easy to guarantee, and the disadvantage is that the weight is relatively large. [4]

Because the load-bearing capacity of fabricated wall panels is generally lower than that of traditional concrete walls, and because of their structural characteristics, they cannot achieve high seismic effects, so they are mostly used in the construction of functional non-load-bearing walls that require high energy-saving performance. However, in the actual application process of traditional fabricated composite wall panels, it is inevitable that there will be cracks caused by the technical reasons of the panel, and it cannot meet the energy-saving requirements of the external wall thermal insulation composite panel.[1]

Therefore, in order to promote the development of prefabricated composite wall panels in China, a new type of prefabricated composite wall structure system should be studied to ensure the seismic performance of the wall while meeting the requirements of energy conservation and environmental protection.

\section{Preparation of bamboo energy-saving composite wall panels}

In order to meet the needs of prefabricated development and improve the energy-saving effect of composite walls, bamboo materials with abundant output, low cost, light weight and high strength can be processed[5], and the excellent thermal insulation and sound insulation properties of foamed concrete can be used to combine the two Into a new type of composite wall material. This bamboo energy-saving composite wall panel has many advantages such as light weight, good fire resistance, heat insulation, sound insulation performance, convenient construction and installation, green and low carbon, energy saving and environmental protection, and

*Corresponding author's e-mail: Ziyang Yu, 2715071373@qq.com 
can be widely used in the field of assembly production of new rural housing in my country.[6]

Bamboo-concrete composite members can greatly improve the ultimate bearing capacity and flexural rigidity of the structure, up to $106 \%$ [7] and $342 \%[8]$, respectively, and the bamboo tendons in the slab can significantly improve the flexural performance of the precast slab.

With the increase in the allocation rate of bamboo bars, the mid-span deflection of the precast slab will gradually decrease. The bamboo energy-saving composite wall is made of cement, sand, and bamboo as the main raw materials. After the concrete is foamed by foaming agent, it is poured into a hollow foam concrete slab equipped with bamboo reinforcement mesh using special equipment. Considering the adaptability of bamboo materials in concrete wall panels, the width of the bamboo ribs is set at $7 \mathrm{~mm} \pm 1 \mathrm{~mm}$, and the thickness is set at $4-5 \mathrm{~mm}$. According to functional requirements, the size of the wall panel can be controlled at a width of $600 \mathrm{~mm}$, a maximum length of $3,000 \mathrm{~mm}$, and a thickness of $100 \mathrm{~mm}$ or $200 \mathrm{~mm}$.[5]

The wallboard is a non-load-bearing component. After the wallboard is manufactured and maintained in the factory to reach the design strength, it is transported to the site for installation. It has the characteristics of convenient installation and fast construction speed. The main production process of prefabricated wallboard includes mold assembly, reinforcement, pouring of foamed concrete, curing, demoulding, and storage.

The common methods of prefabricated composite wall panels in the market include the fixed pedestal method, the assembly line method and the group standing mold method. Among them, the group standing mold method has high production efficiency, small site restrictions, and moderate cost. The board has more advantages. [9] Therefore, the production process of the bamboo energy-saving composite wallboard by the group standing mold method was determined.

The production process of bamboo composite wallboard mainly includes: production preparation, base film placement, wallboard placement, placement of bamboo ribs, pouring foam concrete, top mold placement, maintenance, top mold removal, mold opening, and board ejection. The main production process is shown in Figure 1.

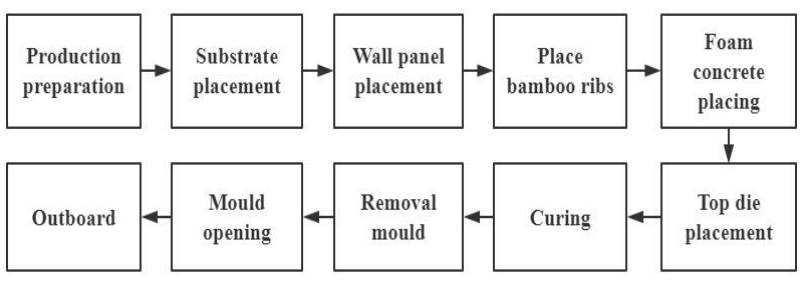

Fig. 1. Production flow chart of bamboo composite wallboard

The prefabricated wall panels made by the group standing mold method should be transported to a special place for secondary maintenance. The ground of the place should be hard and flat, and the panels should not be stacked in layers during the maintenance period. After the secondary maintenance is completed, it should be sent to the testing site for factory quality inspection, and the wall panels that meet the requirements should be packed in bundles and transported to the stacking site. Note that the stack should not exceed 3 layers. The above-mentioned maintenance and stacking places should be protected from rain and moisture.

\section{Technical improvement of prefabricated composite insulation wall system}

In addition to optimizing the plate material of the fabricated composite wall panel to make it have more excellent energy-saving effects, improving the fabricated wall structure can also better solve the inherent problems of weak seismic resistance and low bearing capacity, and can further Reduce the weight and thickness of the wall, and improve the functional performance of heat preservation and heat insulation.

In some locations with low requirements for loadbearing capacity or when used as filling walls, an appropriate amount of aerated concrete blocks can be filled in the inner partition of the fabricated wall panel, which not only improves the insulation capacity of the wall but also reduces the weight of the wall. [10] In the improvement of the outer partition structure, galvanized steel wire concrete with a thickness of about $50 \mathrm{~mm}$ can be used as the wall protection layer, which can prevent the inner core insulation layer from directly contacting the outside, and can also play a role in fire prevention and moisture prevention.

The importance of connecting nodes in the construction of external walls cannot be ignored. The treatment of horizontal and vertical joints of prefabricated composite wall panels is the key point of prefabricated building construction and the key to achieving a comfortable indoor environment. [11] Based on the structural characteristics of the fabricated wall, the following suggestions are put forward for the treatment of the wallboard gaps: use high and low joints for waterproofing between the transverse joints, and use elastic insulation caulking materials to ensure the overall continuity of the insulation layer; for the wallboard For vertical joints, the outer partition is installed with insulation materials to block the insulation layer, the inner partition is made of post-poured concrete to form an airtight layer, and the exterior is waterproofed by materials or cavities to complete the waterproof layer. In the concrete construction of the connection node of the assembled composite wall, the sandwich insulation external wall panel and the shear wall can be installed first, then the frame body is installed to install the laminated beam and the laminated panel, and finally the structural column, the beam-column plate node and the laminated panel are poured. The upper concrete of the plywood connects the entire floor into a stable structure. 


\section{Construction process}

The process of the fabricated composite wall panel construction method mainly includes: composite wall panel production, grassroots treatment, installation and connection of metal parts, wall panel installation, door and window opening reinforcement, and seam treatment. The specific construction process is shown in Figure 2. When customizing and installing prefabricated composite wall panels, it is necessary to meet the basic accuracy requirements. The detailed dimensional deviation and installation allowable deviation are shown in Table 1.

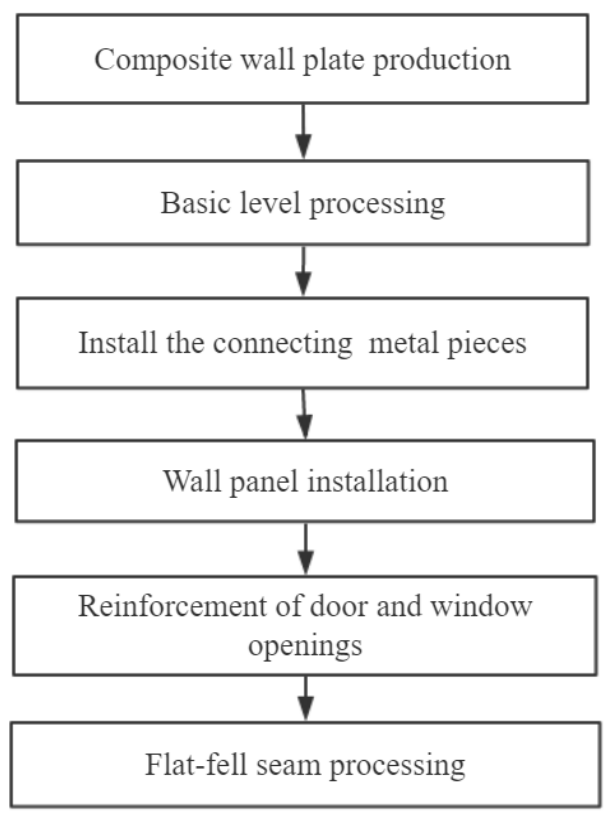

Fig. 2. Flow chart of prefabricated wall panel construction

Table 1. Composite wallboard size and installation allowable deviation

\begin{tabular}{|c|c|c|}
\hline Item & $\begin{array}{c}\text { Allowable } \\
\text { deviation } / \mathbf{m m}\end{array}$ & $\begin{array}{c}\text { Inspection } \\
\text { method }\end{array}$ \\
\hline Length & \pm 5 & - \\
\hline Width & \pm 2 & - \\
\hline Thickness & \pm 1 & - \\
\hline Flat surface & $\leq 2$ & $\begin{array}{c}\text { Check with feeler } \\
\text { gauge or level } \\
\text { meter }\end{array}$ \\
\hline $\begin{array}{l}\text { Diagonal } \\
\text { difference }\end{array}$ & $\leq 6$ & $\begin{array}{c}\text { Diagonal } \\
\text { inspection ruler } \\
\text { inspection } \\
\end{array}$ \\
\hline Lateral bending & $\mathrm{L} / 1000$ & $\begin{array}{l}\text { steel ruler or total } \\
\text { station inspection }\end{array}$ \\
\hline $\begin{array}{c}\text { Wall axis } \\
\text { displacement }\end{array}$ & \pm 5 & $\begin{array}{l}\text { Theodolite or steel } \\
\text { ruler inspection }\end{array}$ \\
\hline Surface flatness & \pm 3 & $\begin{array}{l}\text { Check with ruler } \\
\text { and feeler gauge }\end{array}$ \\
\hline $\begin{array}{l}\text { Verticality of the } \\
\text { elevation }\end{array}$ & \pm 3 & $\begin{array}{l}\text { Inspection of the } \\
\text { vertical inspection } \\
\text { ruler }\end{array}$ \\
\hline $\begin{array}{l}\text { Seam height } \\
\text { difference }\end{array}$ & \pm 2 & $\begin{array}{l}\text { Straightedge and } \\
\text { feeler gauge } \\
\text { inspection }\end{array}$ \\
\hline
\end{tabular}

\begin{tabular}{|c|c|c|}
\hline $\begin{array}{c}\text { Yin and Yang } \\
\text { angle square }\end{array}$ & \pm 3 & $\begin{array}{c}\text { square ruler and } \\
\text { feeler gauge } \\
\text { inspection }\end{array}$ \\
\hline $\begin{array}{c}\text { Center deviation } \\
\text { of door and } \\
\text { window opening }\end{array}$ & \pm 3 & $\begin{array}{c}\text { Steel ruler } \\
\text { inspection }\end{array}$ \\
\hline $\begin{array}{c}\text { Door and window } \\
\text { opening size } \\
\text { deviation }\end{array}$ & \pm 4 & $\begin{array}{c}\text { Steel rule } \\
\text { inspection }\end{array}$ \\
\hline
\end{tabular}

Finally, some suggestions are put forward for the specific construction technology of fabricated composite wallboard. Wall panels can be installed dry, and the base layer floating soil should be removed from the joints of the panels to keep the base layer clean and dry; stainless steel expansion bolts should be used to fix the metal components; the wall panels should be spliced smoothly, and the installation is completed Then, check the wall installation deviation in time; flat steel can be added at the connection part of the wall panel and doors and windows for reinforcement.

\section{Summary}

- In practical applications, fabricated composite wall panels will have larger dead weight, thermal insulation and other properties that cannot meet the higher energy-saving requirements of green buildings. In order to solve this problem, when prefabricating composite wallboards, processing lightweight and high-strength bamboo materials, combined with foam concrete to form a new type of bamboo energy-saving composite wallboard, give full play to the excellent performance of the two heat insulation and sound insulation, improve The energy-saving grade of the wallboard plays a positive role in saving natural resources.

- Due to its structural characteristics, prefabricated composite wall panels have inherent problems such as weak seismic resistance and low bearing capacity. In response to these problems, the structural system of the fabricated composite wall should be optimized, the inner partition is filled with aerated concrete blocks, the outer partition is made of galvanized copper wire concrete protective layer, and attention should be paid to the horizontal and vertical joints during the construction of the connection nodes. The seam treatment is connected with the entire floor to form a stable structure, which improves the stability and load-bearing capacity of the prefabricated building.

\section{Acknowledgments}

This work was supported by the Jiangsu Province Innovative Training Project. (No.202011276060Y)

\section{References}

1. Lu S, Ning Yan. Research on the design criteria of prefabricated houses based on the whole life of the 
project[J]. Construction Economics, 2018, 39(06): 53-56.

2. Li Y X. Experimental study on seismic performance of selected fabricated composite wall panels [J]. Adhesion, 2021, 45(02): 123-126.

3. Guiding Opinions of the General Office of the State Council on Vigorously Developing Prefabricated Buildings (Guobanfa [2016] No. 71) [L].2016-09.

4. $\mathrm{Li} \mathrm{L} \mathrm{L.} \mathrm{Research} \mathrm{on} \mathrm{the} \mathrm{bearing} \mathrm{performance} \mathrm{of}$ prefabricated steel structure residential sandwich composite external wall panels and their joints[D]. Hefei: Hefei University of Technology, 2018.

5. Zhu L F, Hong Kong Liang, Qiu Guorong. Research and application of foundation pit protection of split bamboo soil nail wall [J]. Construction Technology, 2014, 43 (19): 20-23, 28.

6. Sun L J, Pang W X, Sun Y G, Li C F, Liu N. Construction technology of fabricated bamboo energy-saving composite wall [A]. Zhejiang Civil Engineering Society. Proceedings of the 26th Civil Engineering Construction Technology Exchange Conference in Six Provinces and One City in East China (Volume 1) [C]. Zhejiang Civil and Architectural Society: Construction Technology Editorial Department, 2020:4.

7. WEI Y,JI X W,ZHOU M Q,et al.Mechanical properties of bamboo-concrete composite structures with dowel-type connections [J].Transactins of the Chinese Society of Agricultural Engineering,2017,33(3):65-72.

8. WANG Z Y,WEI Y,LIN,et al. Flenxural behavior of bamboo-concrete composite beams with perforated steel plate connections [J]. Journal of Wood Science,2020,66(4):1-20.DOI:10.1186/s10086-0201854-9.

9. Sun Y G, Pang W X, Sun L J, Li C F, Liu N. Research on the production process of fabricated bamboo energy-saving composite wallboard [A]. Zhejiang Civil Engineering and Architecture Society. Paper of the 26th Civil Engineering Construction Technology Exchange Conference of Six Provinces and One City in East China Collection (Volume 1) [C]. Zhejiang Civil Engineering and Architecture Society: Construction Technology Editorial Department, 2020:4.

10. Zheng Z H, Zhong J X, Xie B. Overview of the development of energy-saving technologies for prefabricated building systems [J]. Building Energy Efficiency, 2020, 48(04): 138-143.

11. Zhang H, Li C X, Zhu Q Y. Analysis of key points in the construction of prefabricated ultra-low-energy buildings using sandwich insulation exterior wall panels-Taking the apartment building of China State Construction Technology Chengdu R\&D Center as an example [J]. Construction Technology, 2019 (01):78-84 